\title{
Effect of Agaricus Sylvaticus (Schaeffer) Extract in Rats Skin Wound Healing
}

\author{
Gildiney Raimunda da Silva ${ }^{1}$, Victor Franklin ${ }^{1}$, Joseanne Meira Cambuí ${ }^{1}$, Danilo Tenório de Almeida ${ }^{1}$, Nilsa Sumie \\ Yamashita Wadt ${ }^{2}$, Vinicius 0 Cardoso ${ }^{3}$ and Erna Elisabeth Bach*3
}

${ }^{1}$ Health Department, Graduation, Nove de Julho University, Brazil

${ }^{2}$ Department of Pharmacy, Paulista University, Brazil

${ }^{3}$ Health Department, Nove de Julho University, Brazil

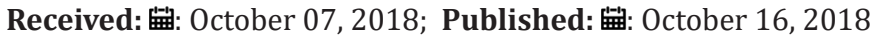

*Corresponding author: Erna Elisabeth Bach, UNINOVE, Biomedical Science, São Paulo, Brazil

\begin{abstract}
Mushrooms are an excellent food option for diets, since they are nourishing and not fattening, mainly due to their nutritional characteristics. They have a high protein content, low lipid values, besides the presence of vitamins (thiamine, riboflavin, niacin), minerals (calcium, iron, phosphorus), beta-glucans and antioxidant compounds. Several people are using it in Brazil as a blood glucose level controller and Anvisa released the Agaricus blazei as a nutraceutical product. In the present project the objective was to evaluate the healing of open cutaneous wounds in rats treated with topical use of Agaricus sylvaticus extract $10 \%$ in gel by macroscopic analysis of the cicatricial process. For skin healing of wound in rats, a total of 15 adults male Wistar rats (UNINOVE Vivarium) were used, divided in three groups. Animals in group 1 were treated with $1 \mathrm{~mL}$ of gel at $10 \%$ Agaricus; group 2 with $1 \mathrm{~mL}$ of distilled aqueous gel and group 3 with fibrinase. Daily applications were performed over the wound of total $4 \mathrm{~cm}^{2}$ area in dorsal region of each animal. The wound evaluation was made macroscopically in the time stamps of 0,7 , and 14 days, and the wound evolution, and skin healing retraction measures evaluated by digital planimetry.
\end{abstract}

Results indicated that extract from Agaricus presented proteins, phenols and beta glucan. As phenols chlorogenic, cafeic, coumaric and benzoic acid were presented and provided antioxidant reaction. The animals treated with Agaricus showed increased healing when compared with control and fibrinase treatment. After 14 days, the wounds in animals treated with Agaricus were healed corresponding to $73.79 \%$ of control group, while animals with fibrinase corresponded to $56,58 \%$ of control group. This demonstrates that fibrinase was not as efficient as Agaricus and when compared to control group. Thus, since Agaricus has an antioxidant factor and acted as a healing agent, it can be stated that the presence of phenols in the extract was important. It is possible to conclude that the gel with Agaricus is effective at skin healing in rats.

Keywords: Agaricus; Cicatrization; Skin

\section{Introduction}

Mushrooms have been used as a food source since ancient times, due to the believe of its high nutritional value and medicinal potential and were considered a noble ingredient in culinary dishes. Approximately 2000 edible species are known and about 25 of them are commercially grown. Mushrooms are an excellent food source for diets, since they are nourishing and not fattening, mainly because of their nutritional characteristics. They have high protein content (27-48\%), low lipid values (2-8\%), and vitamins (thiamine, riboflavin, niacin), minerals (calcium, iron, phosphorus), beta-glucans and compounds with antioxidant activity [1]. Few things are known about the quality of edible mushrooms grown in Brazil, about its nutritional or medicinal value. The data found on international literature are scare and the cultivation conditions are different from those found in Brazil [2]. Brazil has an immense and unexplored microflora. Wild species have untapped and unknown potential, both from the point of view of production and consumption, as well as secondary metabolites and their biological activity [3,4]. In Brazil, we have ANVISA (National Agency of Healthy Surveillance-Brazil) which released for sale only powder of mushrooms for diet or as nutritional [5]. Currently, Agaricus sylvaticus (Schaeffer), Agaricus blazei (Murril) and Agaricus brasiliensis $\mathrm{S}$. Wasser are similar names.

The beta glucan was one of Agaricus' extracted compounds, which is a polysaccharide polymer naturally found as the largest component of fungi cell wall [6]. Agaricus extracts were found in the laboratory concentrations above $200 \mathrm{mg}$ of beta glucan in addition to proteins and evaluated as an antidiabetic [7] and antitumor effect [4]. About healing that is a process by which an injured tissue is replaced by vascularized connective tissue, whether the lesion has been traumatic or necrotic [8]. Despite the predominance of synthetic substances in the therapeutic arsenal, including anti-inflammatory substances, over the years there has 
occurred the valorization of complementary therapeutic practices like the use of medicinal herbs. Several tests using phytotherapics in the healing process of skin lesions were promising. For example, Aloe Vera (mucilage) was effective in the treatment of cutaneous wounds in normal and diabetic rats [9]. The topical use of the $2 \%$ papain solution also showed good results in this wound in rats [10]. Compounds from mushrooms have also been explored as hypoglycemic, antitumor among others, but nothing has been published about its healing action. The aim of the present study was to evaluate the effect of Agaricus sylvaticus (Schaeffer) extract 10\% gel on the healing of surgical skin wounds in rats using macroscopic analyses.

\section{Materials and Methods}

\section{Agaricus sylvaticus: Preparation and Analysis}

The fruiting bodies of A. sylvaticus were cultivated in Rio Grande do Sul (Brazil) and after harvest, washed in water and dried. Dry fruiting bodies were then milled in a hammer mill equipped with a $1 \mathrm{~mm}$ mesh stainless steel sieve in Firm Vitali Cogumelos. The sieve powder was stored dry until further use. Dry weight was normally found between 7 and 10\% fresh weight. One gram of dry mushroom was homogenizing in $40 \mathrm{~mL}$ of distilled water and maintained in cool for one hour and then filtered with paper filter. Extract was submitted to quantify values of proteins [11], phenols [12] and betaglucan by Lever method [13]. After the quantification, phenols were analyzed by HPLC. Phenolic compounds were separated in a HPLC system (Young Lin YL 9300) equipped with a quaternary gradient pump unit, an UV-vis detector and the column oven (YL9330). The analytical column used was a Kinetex C18 $(4.6 \mathrm{~mm} \times 250 \mathrm{~mm}$ i.d., 5um). The wavelength for UV detection was $340 \mathrm{~nm}$. Elution was carried out at a flow rate of $1.0 \mathrm{ml} / \mathrm{min}$ at $3{ }^{\circ} \mathrm{C}$. The mobile phase A consisted of methanol and the mobile phase B was $0.1 \%$ of acetic acid in water. The injection volume was $20 \mu \mathrm{L}$. The standard phenolic compounds were purchased from Sigma (coumaric acid, ferulic acid, rutin, cafeic acid, quercetin, kaempferol) and dissolved in HPLC grade (methanol). For identification was used specific retention times and the peak areas were automatically measured by software Clarity to get the calibration curve.

\section{Animals}

Male 4-week-old Wistar rats weighing between 250-280g were obtained from UNINOVE (Ethics Committee AN 37/2014). The animals were kept in polypropylene cages (three animals per cage) covered with metallic grids in a room maintained at $23 \mathrm{C}, 55+10 \%$ humidity, $12 \mathrm{~h}$ light and $12 \mathrm{~h}$ dark cycle and fed ad libitum for two weeks before the start of the study. The rats were then randomly divided into three different groups $(\mathrm{N}=5)$ with two repetitions. Animals in group 1 were treated with $1 \mathrm{~mL}$ of gel at $10 \%$ Agaricus; group 2 with $1 \mathrm{~mL}$ of distilled aqueous gel and group 3 with fibrinase. Daily application was performed over the wound of total $4 \mathrm{~cm} 2$ area in dorsal region of each animal. The wound evaluation was made macroscopically in time stamps of 0,7 , and 14 days, and skin healing retraction measures evaluated by digital planimetry.

\section{Antioxidant}

The ABTS + solution was prepared by the reaction of $7 \mathrm{mM}$ ABTS $(5 \mathrm{~mL})$ and $2.45 \mathrm{mM}(88 \mathrm{~mL})$ of potassium persulfate, after incubation at room temperature in the dark for $16 \mathrm{~h}$. It was then diluted with $80 \%$ ethanol to give an absorbance of $0.700 \pm 0.005$ at $734 \mathrm{~nm}$. The ABTS + solution $(2.7 \mathrm{~mL})$ was carefully mixed with $0.3 \mathrm{~mL}$ of the test samples. The reaction mixture could stand at 30 ${ }^{\circ} \mathrm{C}$ for $30 \mathrm{~min}$, and the absorbance at $734 \mathrm{~nm}$ was measured in a spectrophotometer. Trolox samples with the same concentrations were used as standards [14].

\section{Statistical Analysis}

Statistical analysis were performed using Assistat-2012 program (Anova, T student test, Tukey).

\section{Results and Discussion}

\section{Analysis of $A$. sylvaticus}

The fruiting bodies from mushrooms have yellow clear color indicating that the drying was carried out at temperatures not assist caramelization of product. The powder when was finely milled, present solubility in water and that was the product used in the present study. For biochemical analysis, extract from Agaricus was made with cool-water because molecules of proteins were protected containing also a little of phenols and peroxidase activity [7]. When used hot water, more phenols were extracted, and protein decreased giving a brown color in solution corresponding to an oxidation of molecules [2]. Biochemical analysis from powder mushrooms resulted $1.15 \mathrm{mg}$ for proteins, $0.96 \mathrm{mg}$ for phenols and $224 \mathrm{mg}$ for beta-glucan when extract $1 \mathrm{~g}$ of mushrooms powder. In HPLC were observed four peaks with concentration in mMols, that was present: chlorogenic acid, benzoic acid, cafeic acid and coumaric acid (Table 1). Mascaro et al. [7] was observed in TLC presence of coumaric acid and chlorogenic acid and more two unknown bands.

Table 1: Concentration in $\mathrm{mM}$ of phenols present in Agaricus extract by HPLC.

\begin{tabular}{|c|c|c|}
\hline Phenols Standard & Rt & conc $\mathbf{~ m M}$ \\
\hline chlorogenic acid & 2.70 & 11.38 \\
\hline benzoic acid & 3.03 & 226.60 \\
\hline cafeic acid & 3.20 & 2.44 \\
\hline coumaric acid & 3.40 & 13.95 \\
\hline
\end{tabular}

\section{Antioxidants}

The Agaricus extract presented antioxidant activity around $118.32 \mu \mathrm{mol}$ TE (Trolox). $\mathrm{g}^{-1}$, indicating a high activity. Due to the antioxidant action, phenolics cooperate with the reduction of cellular oxidative damage caused by reactive species of oxygen and nitrogen $[15,16]$, as well as in the prevention of cancers, mutations, healing aid and in the control of other chronic degenerative diseases [17].

\section{Animals}

Animals treated with Agaricus + gel showed faster healing than when compared to the control group and with fibrinase. At 7 days, the fibrinase group presented $4.7 \%$ healing compared to control, while the Agaricus group was 54\% (Figure 1). After 14 days, the wounds in animals treated with Agaricus were healed corresponding to $73.79 \%$ of control group, while animals with fibrinase corresponded to $56,58 \%$ of control group. This 
demonstrates that fibrinase was not as efficient as Agaricus and when compared to control group. The fibrinase is the positive control, that is, it has proven healing action, but when compared with the Agaricus gel the healing was $17 \%$ more effective with the gel. The polysaccharides of Agaricus, as $\beta$ - glucan, can assist in the healing because they can form a thin layer and protect against external agents that may damage the tissue. According to LIMA et al. [18], it worked with ascorbic acid shown to have anti-inflammatory and healing effects, guaranteeing a suitable environment and conditions for faster skin repair healing. Thus, since Agaricus has an antioxidant factor and acted as a healing agent, it can be stated that the presence of phenols in the extract was important.

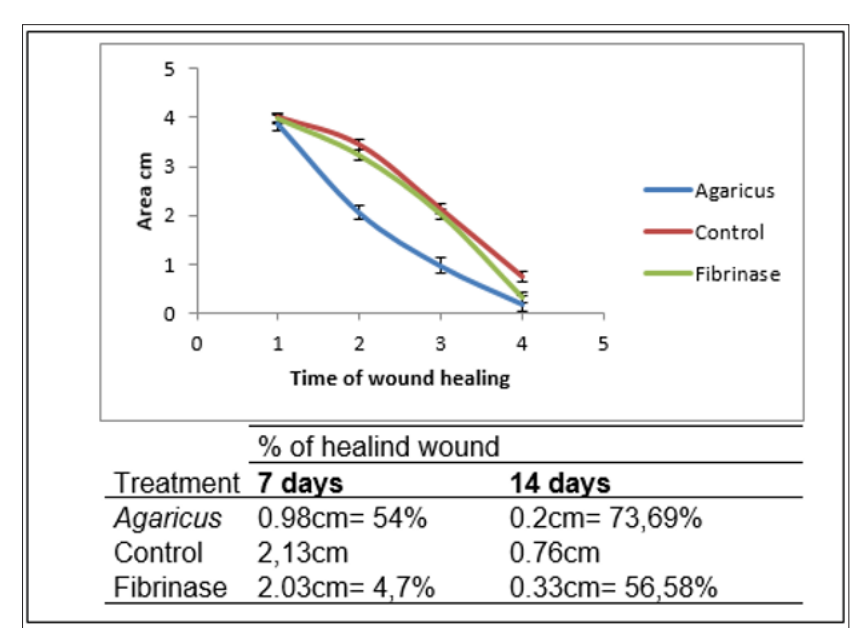

Figure 1: Graphic involved time of wound healing from rats treated with Agaricus-gel, gel-water and fibrinase. Percentage of healing wound included on Table.

\section{Conclusion}

It is possible to conclude that the gel with Agaricus is effective at skin healing in rats.

\section{Acknowledgement}

Financially Supported by $\mathrm{CNPq}$ (Process number: 474681/2013).

\section{References}

1. Zhang M, Cui SW, Cheung PCK, Wang Q (2007) Antitumor polysaccharides from mushrooms: a review on their isolation process, structural characteristics and antitumor activity. Trends in Food Science \& Technology 18(1): 4-19.

2. Bach EE, Florian MC, Wadt NSY, Dellê H, Mascaro MB, et al. (2011) Biotecnologia aplicada em cogumelos: pesquisas realizadas junto a UNINOVE. Anais VI Simpósio Internacional sobre cogumelos no Brasil e V simpósio nacional de cogumelos comestíveis: pp. 147-164
3. Bach EE (2010) Biotecnologia aplicada a cogumelos. In: Marli Gerenutti. Cogumelos medicinais: aspectos de cultivo e aplicações. Sorocaba: EDUNISO p. 11-19.

4. Hi EMB, Bach EE (2011) Avaliação do extrato aquoso de Agaricus blazei em ratos submetidos a tratamento com substância elicitora de célula cancerosa (Pristane). Anais VI Simpósio Internacional sobre cogumelos no Brasil e V simpósio nacional de cogumelos comestíveis.

5. Anvisa (2002) Regulamento Técnico de Substâncias Bioativas e Probióticos Isolados com Alegação de Propriedades Funcional e ou De Saúde. Resolução RDC n. ำ 2, de 7 de janeiro de. Republicada.

6. Bartnicki Garcia S (1968) Cell wall chemistry morphogenesis, and taxonomy of fungi. Annu Rev Microbiol 22: 87-108.

7. Mascaro MB, França CM, Esquerdo KF, Lara MAN, Wadt NSY, et al. (2014) Effects of dietary supplementation with Agaricus sylvaticus Schaeffer on glycemia and cholesterol after streptozotocin-induced diabetes in rats. Evidence-based complementary and alternative medicine p. 1-10.

8. Panobianco MS, Sampaio BAL, Caetano EA, Inocenti A, Gozzo TO (2012) Comparação da cicatrização pós-mastectomia entre mulheres portadoras e não-portadoras de diabetes mellitus. Rev Rene 11: 15-22.

9. Contrera A, Bernardi AC, Pozetti GL, Lopes RA, Contrera MGD (1985) Ação da tintura-mãe de Lichnophora ericoides, Aristolochia esperanzae e Solidago microglossa, em feridas cutâneas de ratos. Rev Esc Farm Odont.11: 157-160.

10. Neto R, R Berindoague, B Barone, DC Teves, MJ Simoes, et al. (1993) Aspectos morfológicos e morfométricos da reparação tecidual de feridas cutâneas de ratos com e sem tratamento com solução de papaína a 2 por cento. Acta Cirúrgica Brasileira 8(1): 18-23.

11. Lowry OH, Rosenbrough NJ, Farr AL, Randall RJ (1951) Protein measurement with the Folin phenol reagent. Journal Biological Chemistry 193: 265-275.

12.Swain R, Hillis WE (1959) The phenolic constituents of Prunus domestica. I.-The quantitative analysis of phenolic constituents. Journal of the Science of Food and Agriculture 10(1): 63-68.

13. Lever M (1972) A new reaction for colorimetric determination of carbohydrates. Analytical Biochemistry 47(1): 273-279.

14. Rufino MSM, Alves RE, Brito ES, Morais SM, Sampaio CG, et al. (2007) Metodologia Científica: Determinação da Atividade Antioxidante Total em Frutas pela Captura do Radical Livre ABTS ${ }^{+}$Comunicado técnico 128 Embrapa. Embrapa Agroindústria Tropical 128: 1-6.

15. Nascimento RJ, Araújo CR, Melo EA (2010) Atividade antioxidante de extratos de resíduo agroindustrial de goiaba (Psidium guajava L.). Alimentos e Nutrição, Araraquara 21(2): 209-216.

16. Nascimento MS, Santana ALBD, Maranhão CA, Oliveira LS, Bieber L (2013) Chapter 13 phenolic extractives and natural resistance of wood. In: Chamy R and Rosenkranz F (Eds.). Biodegradation-life of science. InTech pp. 349-370.

17. Vieira LM, Sousa MSB, Mancini Filho J, Lima A (2011) Fenólicos totais e capacidade antioxidante in vitro de polpas de frutos tropicais. Revista Brasileira de Fruticultura 33(3): 888-897.

18. Lima CC, Pereira APC, Silva JRF, Oliveira LS, Resck MCC, et al. (2009) Ascorbic acid for the healing of skin wounds in rats. Braz J Biol 69(4): 1195-1201. 
ISSN: 2574-1241

DOI: 10.26717/BJSTR.2018.10.001903

Erna Elisabeth Bach. Biomed J Sci \& Tech Res

(c) (P) This work is licensed under Creative

Submission Link: https://biomedres.us/submit-manuscript.php

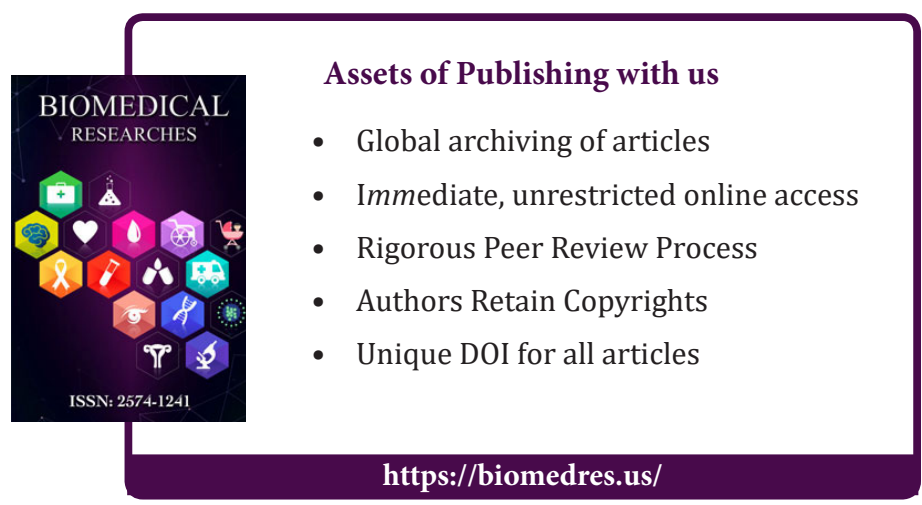

